\title{
Bilateral Breast Metastasis from Mucinous Adenocarcinoma of the Rectum: A Case Report and Review of the Literature
}

\section{Rektum Müsinöz Adenokarsinomundan Bilateral Meme Metastazı: Bir Olgu Sunumu ve Literatürün Gözden Geçirilmesi}

\author{
Rumana MAKHDOOMI, Farhat MUSTAFA, Rayees AHMAD, Suhail MALIK, Sheema SHEIKH, \\ Khalil Mohammad BABA
}

Department of Pathology, Sheri-Kashmir Institute of Medical Sciences (SKIMS), SRINAGAR, INDIA

\begin{abstract}
Metastatic breast carcinoma is rarely seen in clinical practice. It has been reported that lymphoma-leukemia, melanoma and sarcomas can metastasize to the breast. Bilateral metastases to the breast are rare and commonly have been seen to originate from ovarian carcinoma. Adenocarcinoma of rectum metastasizing to breast is an extremely rare clinico-pathological situation. We report a 28 -year-old female who presented with bilateral breast metastasis 9 months after abdomino-perineal resection and total meso-rectal excision for a locally advanced mucinous adenocarcinoma of the rectum. A few case reports of a mucinous adenocarcinoma of rectum presenting with bilateral breast metastasis have been seen in the world literature and we hereby report this case who till now is the youngest patient reported.
\end{abstract}

Key Words: Breast, Metastasis, Rectum, Adenocarcinoma

\section{Öz}

Metastatik meme karsinomuna klinik uygulamada nadiren rastlanır. Lenfoma-lösemi, melanom ve sarkomların memeye metastaz yapabildiğibildirilmiştir. Memeyebilateralmetastaznadirdirvesıklıkla over karsinomundan köken aldıkları görülmüștür. Memeye metastaz yapan rektum adenokarsinomu son derece nadir bir kliniko-patolojik durumdur. Yerel ilerlemiş rektum müsinöz adenokarsinomu için abdominoperineal rezeksiyon ve total mezorektal eksizyon yapılan ve 9 ay sonra bilateral meme metastazı saptanan (28 yaşında bir kadını) hastayı sunuyoruz. Dünya literatüründe bilateral meme metastazıyla gelen birkaç rektum müsinöz adenokarsinomu olgusu bildirilmiştir ve biz de şimdiye kadar bildirilen en genç hasta olan bu olguyu sunuyoruz.

Anahtar Sözcükler: Meme, Metastaz, Rektum, Adenokarsinom

\section{INTRODUCTION}

Metastatic lesions to the breast are rare (1). Lymphomas, leukemias, melanomas and sarcomas are the commonest malignancies that can metastasize to breast (2). Metastasis to the breast from rectal carcinoma is very rare, bilateral breast metastasis being an extremely rare clinicopathological situation $(3,4)$. A few cases of bilateral breast metastasis in the literature have been found to arise from the ovary (2). We hereby report bilateral breast metastasis in a 28 -year-old female who had been operated 9 months back for mucinous adenocarcinoma of the rectum. This is a rare case of bilateral breast metastasis from adenocarcinoma of the rectum and the youngest case reported so far. An accurate diagnosis of breast metastasis is important because the treatment and outcome of primary and metastasis to the breast from gastrointestinal primaries is different.

(Turk Patoloji Derg 2013, 29:231-234)

Received : 03.08.2011 Accepted : 14.03.2012

\section{CASE REPORT}

A 28-year-old, married female presented to us at the FNAC (Fine needle aspiration cytology) clinic with a history of bilateral breast masses for one month. On general physical examination, the patient was emaciated, pale with slight icterus, with no lymphadenopathy - cervical or axillary. Breast examination revealed multiple discrete masses in both breasts, largest on measuring $3 \times 2 \mathrm{~cm}$ and smallest one measuring $2 \times 1 \mathrm{~cm}$. FNAC was done from the largest masses of both breasts. Microscopy showed mucin pools with a few cells showing pleomorphism and a signet ring like morphology (Figures 1,2).

Mammography of both breasts was done three months back. It revealed prominent fibro-glandular tissue with no definite soft tissue nodule. There was no evidence of

Correspondence: Rumana MAKHDOOMI

Department of Pathology, Sheri-Kashmir Institute of Medical Sciences

(SKIMS), Srinagar 190 011, KASHMIR, INDIA

E-mail: rumanahamid@rediffmail.com Phone: +91 1942400621 
interstitial distortion and no micro-calcification was seen Bilateral nipples and retro-alveolar areas appeared normal.

In her past history, nine months back the patient had presented with a history of pain in the lower abdomen and constipation for 5 months. She had also complained of bleeding per rectum for one month. Proctoscopy done revealed a constricting growth, circumferential $3-4 \mathrm{cms}$ from the anal verge. Colonoscopy had revealed a polypoidal growth on the right lateral wall of the rectum.

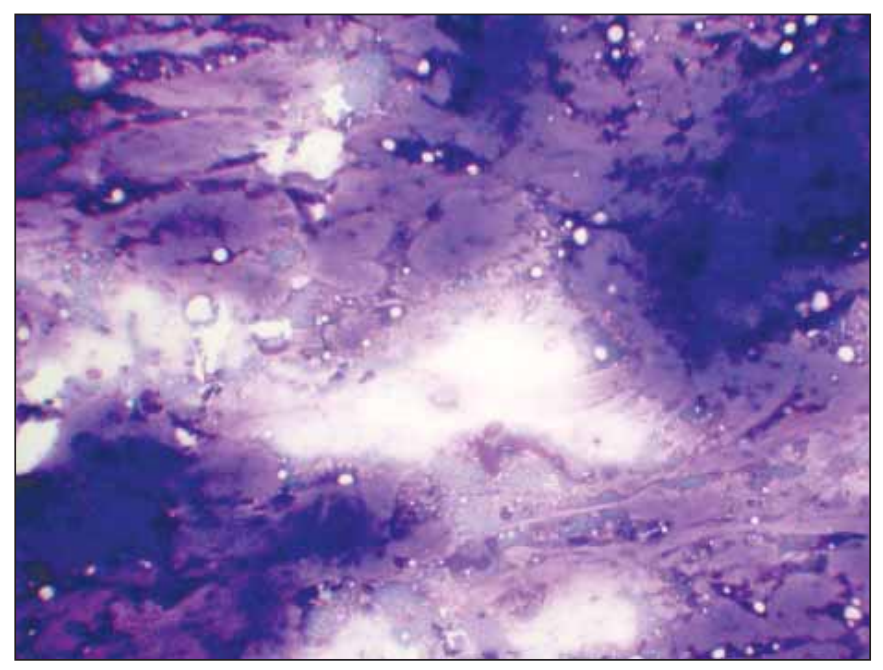

Figure 1: FNAC breast showing mucous pools with occasional pleomorphic cells. MGG (May-Grunwald Giemsa x20).

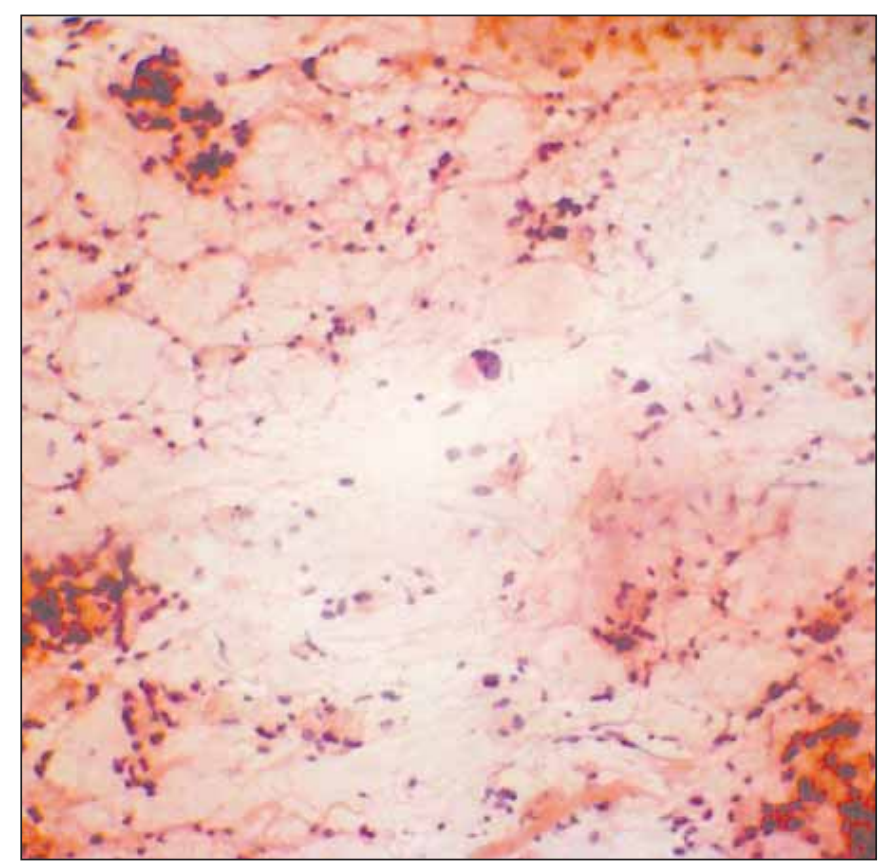

Figure 2: FNAC breast showing pleomorphic cells (PAP x40), with one of the cells showing nucleus pushed to one side (signet ring cell).
Routine blood investigations were normal except for a raised level of carcino-embryonic antigen (CEA) level of $9.6 \mathrm{ng} / \mathrm{ml}$. Contrast enhanced computerized tomography (CECT) of abdomen and pelvis revealed a thick-walled ano-rectal region with small paracentral nodes. Patient underwent an abdomino-perineal resection. Intraoperatively circumferential growth was seen in the rectum, $4 \mathrm{~cm}$ from the anal verge. Growth was free, anteriorly, posteriorly and laterally. Liver was free and no iliac nodes were felt. Postoperative recovery period was uneventful with decrease in CEA levels to $2.3 \mathrm{ng} / \mathrm{ml}$. Histopathology of the resected specimen revealed mucus secreting adenocarcinoma with signet-ring differentiation (Figure 3), dissecting the muscle bundles and extending up to the serosa. Five lymph nodes were infiltrated by malignant cells. Both proximal and distal resection margins were free of tumour.

In view of the history and characteristic mucin pools and signet ring cells, the diagnosis of metastatic mucinous adenocarcinoma of the breast was made. Immunohistochemistry done for breast markers like ER (Estrogen receptor), PR (Progesterone receptor) and Her 2 were negative. The patient is on adjuvant chemotherapy and is doing well after 2 months of follow-up.

\section{DISCUSSION}

Metastases to the breast are relatively uncommon but virtually any malignancy may metastasize to the breast. Most breast metastases originate from the contralateral breast (3). However, lymphomas, leukemias, melanomas, sarcomas, carcinomas from lung, stomach, esophagus, ovary, oropharynx may be associated with metastasis to breast $(1,2)$. Bilateral breast metastases are very rare and have been seen in a few cases of ovarian carcinoma (2).

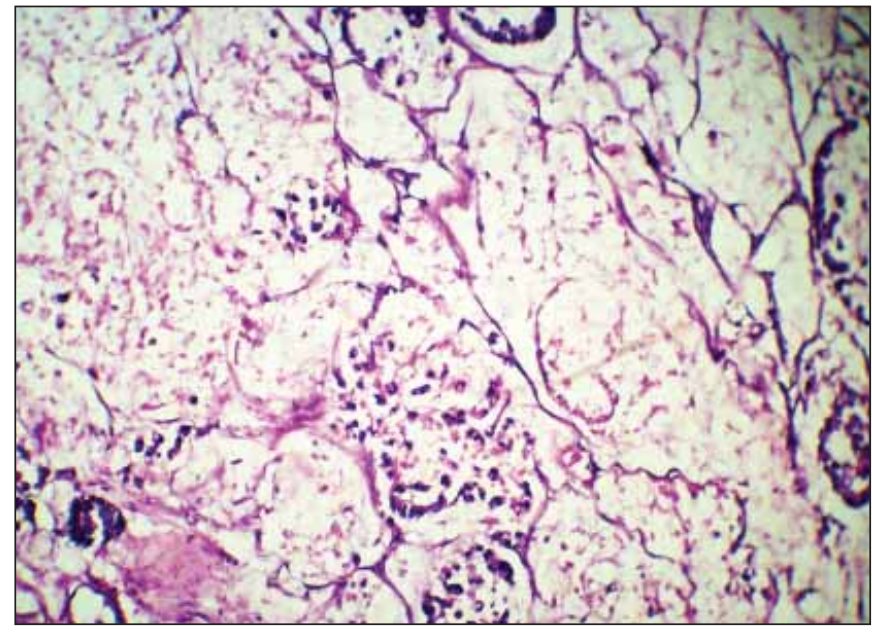

Figure 3: Mucin pools with signet ring cells infiltrating colon (H\&E x20) 
Breast secondaries from a colorectal neoplasm are rare till date and only 19 such cases have been reported, two of them being in men (4-12). However, bilateral breast metastasis from adenocarcinoma of the rectum is very rare, ours being the fourth case in the world literature (6). Based on the review of 19 cases of colorectal carcinoma metastasizing to the breast, Schaekelford et al. reported a majority of cases (55\%) to the left breast with $30 \%$ to the right breast and only 3 cases with bilateral breast metastasis (6). Also, Schaekelford reported non-breast metastasis at the time of diagnosed breast metastasis in 15 cases (75\%). In our case, however, metastasis to other organs was absent after a thorough scanning.

Solitary discrete lesions in the breast are the most common form of presentation (7). Multiple well-defined lesions and diffuse involvement are less common (1). Our case presented with bilateral multiple breast masses varying in size from 0.5 to $3 \mathrm{~cm}$. The lesions were located superficially in both breasts with no nipple retraction. Axillary lymph node involvement is known (7) but it was not seen in our case. Breast metastases may be the first manifestation of the malignant disease (5).

Our patient was a 28 -year-old female, and the average age of patients with metastatic breast cancer is 43.3 years (1). Breast metastases are usually seen in the reproductive age group (30-45 years) (5). Bilateral breast metastasis from ovarian cancer show a mean age of 46 years with a mean interval of 22 months and a mean survival of 12 months (2). Colorectal metastases to breast average $3.5 \mathrm{~cm}$ in size and range in size from 1 to $11 \mathrm{cms}(6)$. The three patients reported with bilateral breast metastasis from adenocarcinoma of colon were aged 74 years, 43 years and 35 years making our patient the youngest patient reported so far $(4,6)$. The first two patients had been operated for colorectal carcinoma two years and two months back respectively, both patients having Duke's stage $(\mathrm{C})$ rectal carcinoma.

The imaging features were not helpful in our case whereas the other two (Ist two) cases mimicked a multifocal primary breast carcinoma owing to the speculated, irregular soft tissue density mammographic appearances (8). The high content of mucin within a tumor may be responsible for some of the atypical imaging features (4). Colorectal carcinoma metastases to breast most often appear as masses without calcifications on mammography; in series of 9 cases with reported mammographic findings 2 (22\%) exhibited micro-calcifications (6).
Radiologic studies of the breast may therefore be misleading as metastasis may be associated with calcifications and may not present as multiple bilateral masses and may mimic a primary mammary carcinoma (4). Metastatic neoplasms to the breast may be diagnosed by fine needle aspiration cytology (12) and in clear-cut cases the need for biopsy may not be there.

Mucinous differentiation of colorectal cancer is known to be associated with a poor outcome (13). In our patient, the rectal tumor showed histological features of mucinous differentiation. The features displayed were not typical enough to sub-categorize this into signet ring cell subtype. The metastatic cells showed pools of mucous with a few signet rings. Metastatic breast cancer from rectum has been reported earlier in a patient who defaulted from oncological treatment (3). However our patient was on a regular followup and doing well.

Colorectal carcinoma (CRC) metastasizing to breast needs to be distinguished from primary mucinous carcinoma of the breast, and the histo-morphologic clues of a metastatic CRC such as the presence of 'dirty' necrosis can be helpful. Metastatic CRC can morphologically mimic a primary poorly differentiated ductal carcinoma of the breast. Histopathological clues of metastases include lack of an in-situ component, prominent lympho-vascular space invasion and a 'triple-negative' phenotype.

Immunohistochemistry in a vast majority of cases identifies the phenotype of carcinoma, CRC is positive for cytokeratin 20, CDX2 and negative for breast markers cytokeratin-7, mammaglobin and ER and PR in greater than $90 \%$ of cases (5). Immunohistochemistry done for breast markers i.e, ER, PR, Her 2 was negative in the primary adenocarcinoma of rectum. The likelihood of a primary breast cancer metastasizing to the colon was therefore ruled out in our case. In our patient, the mode of spread was likely hematogenous. The low rate of metastasis of gastrointestinal cancers to breast can be explained by the fact that gastrointestinal malignancies commonly metastasize by way of the portal route (14).

The reason why this tumor metastasized to both breasts and not other organs is not clear. Only further studies will tell whether this is part of a syndrome in which there was a similar tumor arising from both breasts and also from the rectum or the breasts in this patient were genetically predisposed to receive metastatic deposits from rectum. 


\section{REFERENCES}

1. Toombs BD, Kalisher L: Metastatic disease to the breast: Clinical, pathologic and radiographic features. AJR Am J Roentgenol 1977, 129:673-676

2. Lee SK, Kim WW, Kim SH, Hur SM, Kim S, Choi JH, Cho EY, Han SY, Hahn BK, Choe JH, Kim JH, Kim JS, Lee JE, Nam SJ, Yang JH: Characteristics of metastasis in the breast from extramammary malignancies. J Surg Oncol 2010, 101(2):137-140

3. Hisham RB, Thuaibah H,Gul YA: Mucinous adenocarcinoma of the rectum with breast and ocular metastasis. Asian J Surg 2006, 29:95-97

4. Wakeham NR, Satchithananda K, Svensson WE, Barrett NK, Comitis S, Zaman N, Ralleigh G, Sinnett D, Shousha S, Lim AK: Colorectal breast metastases presenting with atypical imaging features. Br J Radiol 2008, 81:149-153

5. Singh T, Premalatha CS, Satheesh CT, Lakshmaiah KC, Suresh TM, Babu KG, Ramachandra C: Rectal carcinoma metastasizing to the breast: A case report and review of literature. J Can Res Ther 2009, 5:321-323

6. Shackelford RE, Nandyala PA, Bui MM, Kiluk JV, Esposito NN: Primary colorectal adenocarcinoma metastatic to the breast: Case report and review of nineteen cases. Case Reports in Medicine 2011, 2011:738413

7. Perin T, Canzonieri V, Memeo L, Massarut S: Breast metastasis of primary colon cancer with micro-metastasis in the axillary sentinel node. A metastasis that metastasized. Diagnostic Pathology 2011, 6:45
8. Muttarak M, Nimmonrat A, Chaiwun B: Metastatic carcinoma to male and female breast. Australas Radiology 1998, 42:16-19

9. Nielsen M, Andersen JA, Henriksen FW, Kristensen PB, Lorentzen M, Ravn V, Schiødt T, Thorborg JV, Ornvold K: Metastases to the breast from extra-mammary carcinomas. Acta Pathol Microbiol Scandanavia 1981, 89:251-256

10. Sanchez LD, Chelliah T, Meisher I, Niranjan S: Rare case of breast tumor secondary to rectal adenocarcinoma. South Med J 2008, 10:1062-10624

11. Del Prete C, Del Prete SA, Babkouski RC: Breast metastasis from colonic primary: A case report and review of the literature. Conn Med 2009, 73:399-402

12. David O, Gattuso P, Razzan W, Moroz K, Dhurandhar N: Unusual cases of metastasis to the breast. A report of 17 cases diagnosed by fine needle aspiration. Acta Cytol 2002, 46:377-385

13. Purdie CA, Piris J: Histopathological grade, mucinous differentiation and DNA ploidy on relation to prognosis in colorectal carcinoma. Histopathology 2000, 36:121-126

14. Shields CL, Shields JA, Gross NE, Schwartz GP, Lally SE: Survey of 520 eyes with uveal metastases. Ophthalmology 1997, 104: $1265-1276$ 